\title{
UPAYA MENANAMKAN NILAI-NILAI ENTREPRENEURSHIP UNTUK MEMBEKALI KECAKAPAN HIDUP ( LIFE SKILL ) SEJAK DINI PADA PESERTA DIDIK
}

\author{
SUTINI \\ MTs Negeri 2 Temanggung, Jawa Tegah \\ E-mail : sutini.maryoto@gmail.com
}

\begin{abstract}
ABSTRAK
Penelitian ini bertujuan untuk mengkaji betapa pentingnya menanamkan nilai-nilai entrepreneurship kepada peserta didik di era globalisasi ini, melalui studi literatur. Teknik yang digunakan untuk mengumpulkan data adalah dengan cara dokumentasi, yaitu mengumpulkan berbagai macam sumber literatur yang terkait dengan topik penelitian. Selanjutnya berbagai macam sumber literatur yang terkumpul di review, dianalisis menggunakan metode deskriptif kualitatif secara rinci dan mendalam, kemudian disimpulkan. Gaung globalisasi menyebabkan tingginya persaingan antar individu dalam segala bidang, memaksa agar para peserta didik dibekali dengan kecakapan hidup ( life skill ) melalui penanaman nilai-nilai entrepreneurship sehingga mereka dapat menjalani kehidupan yang lebih baik ke depannya setelah lulus dari sekolah. Mereka harus mampu mengubah pola pikir "setelah lulus mencari kerja, menjadi setelah lulus meciptakan lapangan pekerjaan". Sekolah sebagai lembaga pendidikan formal mempunyai peran yang sangat strategis dalam mewujudkan tujuan tersebut. Penanaman nilainilai entrepreneurship di sekolah dapat dilakukan dengan beberapa cara antara lain melalui proses pembelajaran dan pemanfaatan Koperasi sekolah. Melalui peran koperasi sekolah, peserta didik dilatih untuk belajar berwirausaha, sehingga diharapkan memiliki kemandirian yang tinggi. Selain itu, sekolah juga dapat membiasakan menanamkan nilai-nilai entrepreneurship kepada peserta didik melalui budaya sekolah yang disepakati bersama.

Kata kunci : nilai-nilai entrepreneurship, kecakapan hidup ( life skill) dan peserta didik
\end{abstract}

\section{AN EFFORT TO INSTILL ENTREPRENEURIAL VALUES AS LIFE SKILL OF STUDENT FROM AN EARLY AGE}

\begin{abstract}
This study aims to examine the importance of instilling entrepreneurial values in students in this era of globalization, through literature studies. The technique used to collect data is user documentation, which is collecting various kinds of literature sources related to the research topic. Various kinds of literature sources were collected in a review, analyzed using a detailed and in-depth qualitative descriptive method, then further. The echo of globalization causes competition between individuals in all fields, refugees so that students are equipped with life skills that instill entrepreneurial values so that they can live a better life after graduating from school. They must be able to change the mindset "after graduating from work, to create jobs after graduating". Schools as formal educational institutions have a very strategic role in realizing these goals. The cultivation of entrepreneurial values in schools can be done in several ways, including through the learning process and the use of school cooperatives. Through school cooperatives, students learn entrepreneurship, so they are expected to have high independence. In addition, schools can also get used to instilling entrepreneurial values in students through a mutually agreed-upon school culture.
\end{abstract}

Keywords: entrepreneurial values, life skill, students

\section{PENDAHULUAN}

Istilah entrepreneur diterjemahkan sebagai wirausaha atau wiraswasta. Sedangkan entrepreneurship diterjemahkan sebagai kewirausahaan. Menurut Sarosa (2005), entrepreneur adalah seseorang yang mempunyai visi, semangat dan melakukan tindakan-tindakan nyata 
dalam usaha menciptakan dan mengembangkan sendiri sumber-sumber income nya tanpa ketergantungan terhadap orang lain. Sedangkan menurut Suryana (2006), entrepreneurship adalah suatu disiplin ilmu yang mempelajari tentang nilai, kemampuan (ability) dan perilaku seseorang dalam menghadapi tantangan hidup dan cara memperoleh peluang dengan bermacam-macam resiko yang mungkin dihadapinya. Entrepreneurship juga diartikan sebagai suatu jiwa, sikap dan kemampuan dari seseorang untuk menciptakan sesuatu yang baru yang sangat bernilai dan bermanfaat baik itu untuk dirinya sendiri maupun untuk orang lain (Sakdiyah : 2010).

Dewasa ini jiwa entrepreneurship sangat dibutuhkan, agar seseorang dapat bertahan dan mampu hidup serta menjalani kerasnya zaman. Persaingan antar individu yang semakin tinggi di era globalisasi ini, menggugah dunia pendidikan untuk menanamkan jiwa entrepreneurship ke dalam pembelajaran. Melihat kenyataan tersebut, saat ini gerakan untuk menggaungkan dan memajukan entrepreneurship atau kewirausahaan semakin santer terdengar, Pemerintah melalui Kementerian Pendidikan Dasar dan Menengah serta Kementerian Riset dan Pendidikan Tinggi memberikan anjuran kepada semua sekolah/madrasah dan perguruan tinggi untuk menyertakan pembelajaran entrepreneur ke dalam kurikulum pendidikan. Kita sadari bersama bahwa usaha tersebut tidak terjadi secara tiba-tiba dan tidak semudah membalik telapak tangan. Menurut Suriani (2014), proses pembentukan entrepreneurship membutuhkan proses pembelajaran yang berlangsung dalam kurun waktu yang sangat panjang. Oleh karena itu, kurikulum pembelajaran entrepreneurship ini diberikan sejak pendidikan usia dini hingga perguruan tinggi.

Di sekolah/madrasah pembelajaran entrepreneurship ini dimaksudkan untuk membentuk peserta didik yang memiliki kemampuan sebagai seorang innovator ( Nasution, 2007 ). Selain itu menurut Suriani (2014), pembelajaran entrepreneur juga untuk membentuk peserta didik yang memiliki perilaku, semangat dan kemampuan untuk merespon secara positif terhadap kesempatan yang ada, untuk memperoleh keuntungan bagi dirinya sendiri maupun masyarakat.

Pendidikan entrepreneur mempunyai peran dan manfaat yang sangat luas. Melalui pendidikan entrepreneur peserta didik akan dibentuk menjadi pribadi yang mempunyai kemandirian tinggi, tanpa harus memiliki ketergantungan terhadap orang lain termasuk dalam mengambil keputusan. Menurut Fatimah (2014), seorang entrepreneur adalah pekerja keras dan orang yang sangat mandiri. Beberapa manfaat yang dapat diperoleh dari entrepreneurship antara lain adalah 1) peluang untuk mengendalikan nasib sendiri 2) peluang untuk mencapai potensi sepenuhnya 3) peluang untuk melakukan perubahan 4) peluang untuk berperan dalam masyarakat 5) peluang untuk mendapatkan pengakuan masyarakat 6) peluang untuk memperoleh keuntungan tanpa batas 7) peluang untuk melakukan sesuatu yang disukai.

Pendidikan entrepreneur sangat erat kaitannya dengan pendidikan kecakapan hidup (life skill). Life skill dari sisi etimologi adalah istilah dari bahasa Inggris, dalam bahasa Indonesia lebih dikenal dengan istilah kecakapan hidup. Menurut Departemen Pendidikan Nasional dalam Kamus Besar Bahasa Indonesia (2008), kecakapan hidup adalah kemampuan yang dimiliki seseorang untuk dapat hidup. Definisi yang lain bahwa kecakapan hidup adalah kecakapan seseorang untuk beradaptasi dan berperilaku positif sehingga menyebabkan seorang individu untuk melakukan reaksi secara efektif dalam menghadapi kebutuhan dan tantangan sehari-hari ( Tim Pengembang Ilmu Pendidikan : 2007). Sedangkan menurut Anwar ( 2006 ), life skill diartikan sebagai kemampuan seseorang yang diperlukan untuk beradaptasi dan berinteraksi dengan masyarakat dan lingkungannya berupa keterampilan dalam pengambilan keputusan, pemecahan masalah, berpikir kreatif, berpikir kritis, membina hubungan antar pribadi, berkomunikasi efektif, mempunyai empati dan dapat mengatasi stes serta emosi. Jika seorang individu memiliki kecakapan hidup maka ia akan sanggup, berani menghadapi hidup dengan segala permasalahannya tanpa rasa tertekan dan mampu secara proaktif dan kreatif untuk mencari solusi guna mengatasi problema kehidupannya (Muhaimin : 2003)

Sekolah sebagai lembaga formal berperan sangat penting dalam menanamkan nilai-nilai entrepreneur bagi generasi muda. Sebagia lembaga pendidikan dasar sekolah dituntut untuk 
dapat memberi bekal kepada lulusannya, sebagai generasi penerus bangsa yang mempunyai pondasi karakter yang kuat agar dapat bertahan di tengah persaingan global yang akan dihadapi di hari depannya. Memberikan pendidikan entrepreneur kepada peserta didik diharapkan dapat membekali mereka dengan kecakapan hidup yang akan sangat bermanfaat untuk menjalani kehidupan selanjutnya. Pendidikan kecakapan hidup berorientasi kepada peserta didik agar mempunyai kemampuan dan modal dasar sehingga mereka kelak bisa hidup secara mandiri dan survive terhadap tekanan yang ada di sekitarnya.

\section{METODE PENELITIAN}

Metode yang digunakan dalam penelitian ini adalah metode studi literatur. Teknik yang digunakan untuk mengumpulkan data adalah dengan cara dokumentasi, yaitu mengumpulkan berbagai macam sumber literatur yang terkait dengan topik penelitian seperti artikel jurnaljurnal ilmiah , berita-berita online dan buku-buku referansi yang relevan. Selanjutnya berbagai macam sumber literatur yang terkumpul di review, dianalisis menggunakan metode deskriptif kualitatif secara rinci dan mendalam, kemudian langkah akhir adalah menyimpulkan.

\section{HASIL DAN PEMBAHASAN}

Saat ini, terdapat beberapa permasalahan pada generasi muda Indonesia pada umumnya, yaitu sebagian dari mereka mempunyai minat dan motivasi yang rendah untuk berwirausaha. Hal ini tentu saja menjadi masalah serius bagi pemerintah, industri, dunia pendidikan dan masyarakat. Untuk itu agar masalah tersebut dapat teratasi, dibutuhkan solusi terbaik agar minat berwirausaha pada generasi muda dapat tumbuh sehingga dapat menjadi bekal untuk kehidupan mereka di lingkungan dengan daya saing yang tinggi.

Perlu kita sadari bersama bahwa jumlah pengangguran di Indonesia saat ini cukup memprihatinkan. Menurut catatan Badan Statistik (2020), pada bulan Agustus 2020 jumlah angkatan kerja di Negara kita mencapai 138,22 juta orang. Namun dari jumlah tersebut yang bekerja sebanyak 128,45 juta orang, sehingga mereka yang tidak bekerja adalah 10,77 juta orang. Banyaknya lulusan sekolah / sarjana yang menganggur tersebut karena mereka mencari lapangan pekerjaan, tetapi tidak berusaha menciptakan lapangan pekerjaan. Jiwa entrepreneur inilah yang akan mampu menciptakan lapangan pekerjaan baru, sehingga juga mampu menyerap tenaga kerja. Terbentuknya mental kewirausahaan pada generasi muda akan dapat membantu menciptakan lapangan kerja baru, yang akan dapat menyerap tenaga kerja dimasa yang akan datang (Dongoran, Nisa Sihombing \& Purba : 2016). Upaya yang harus dilakukan sekolah saat ini adalah menanamkan karakter dan jiwa entrepeneurship kepada peserta didik sejak awal, dengan menerapkan metodologi dan prinsip-prinsip pembentukan life skill. Paradigma seorang entrepreneur harus ditumbuhkembangkan melalui proses pembelajaran. Menurut Kemendiknas (2016), pendidikan dasar dapat mengimplementasikan nilai-nilai pokok entrepreneurship secara bertahap antara lain 1) kemandirian 2) kreatif 3) berani mengambil resiko 4) berorientasi pada tindakan 5) kepemimpinan dan 6) sukses.

Banyak terobosan yang dapat dilakukan oleh sekolah untuk menumbuhkan jiwa entrepreneur pada diri peserta didiknya, melalui proses pembelajaran yang dilakukan seharihari di sekolah. Karakteristik peserta didik dan tingkatan jenjang pendidikan tentu saja akan sangat berpengaruh terhadap pilihan cara yang akan diterapkan. Pembekalan kecakapan hidup ( life skill) pada peserta didik dengan cara menumbuhkan jiwa entrepreneurship dapat dilakukan melalui beberapa cara antara lain :

Salah satu contoh pengaplikasian pendidikan kewirausahaan pada peserta didik adalah program Market Day. Fungsi dari kegiatan ini bagi peserta didik adalah untuk melatih jiwa entrepreneur, melatih kreativitas dan inovasi serta pemahaman terhadap dunia bisnis ( Zultiar \& Leonita, S. : 2017). Program Market Day merupakan program yang dilaksanakan oleh sekolah-sekolah mulai dari tingkat PAUD sampai dengan tingkat Pendidikan Menengah Atas, sebagai program pengembangan keterampilan peserta didik dalam berwirausaha. Jika keterampilan wirausaha ini diterapkan dan dikembangkan sejak dini, maka akan menjadi 
pondasi yang kuat untuk menumbuhkan jiwa entrepreneur. Keterampilan kewirausahaan (entrepreneurship) ini merupakan kemampuan peserta didik sebagai bentuk penguasaan pengetahuan yang kelak akan diterapkan dalam kehidupannya (Saroni : 2012 ). Selain untuk menumbuhkembangkan jiwa entrepreneurship, kegiatan Market day yang dilaksanakan di sekolah sekaligus juga dapat dijadikan sarana untuk penguatan karakter siswa seperti rasa percaya diri, mampu berkomunikasi dan dapat melatih kecerdasan bisnis peserta didik.

Program Market Day ini adalah bentuk pengembangan model pembelajaran Project Based Learning (PBL), yang dikemas dalam istilah Project Based Learning Market Day. Model pembelajaran ini merupakan model pembelajaran yang berbasis proyek yang melibatkan peserta didik untuk merekonstruksi pengetahuan, keterampilan dan mengkulminasikannya dalam produk nyata, serta memasarkan produk tersebut pada teman, guru atau masyarakat sekitar melalui bazar atau pasar yang diselenggarakan oleh sekolah.

Ada enam langkah kerangka dasar design pelaksanaan PBL Market Day yaitu 1) menentukan permasalahan mendasar yang akan digunakan untuk sebuah proyek yang menuntut penyelesaian; 2) mendesain proyek; 3) menyusun jadwal pelaksanaan proyek; 4) memonitor kemajuan proyek; 5) menguji proses dan hasil dan 6) mengevaluasi pengalaman membuat proyek. Pelaksanaan Market Day ini akan mampu menumbuhkan kreativitas, inovasi dan life skill dibidang kewirausahaan, sehingga dalam diri mereka akan tumbuh semangat dan daya saing dalam berwirausaha (Rohmah : 2020 ).

Koperasi sekolah merupakan organisasi yang didirikan di lingkungan sekolah, yang beranggotakan guru dan siswa sekolah yang bersangkutan. Pendirian Koperasi sekolah ini dalam rangka menanamkan pendidikan koperasi kepada peserta didik. Menurut Nurbudiyani ( 2013 ), koperasi sekolah mempunyai ciri-ciri sebagai berikut 1) didirikan untuk kegiatan pembelajaran peserta didik; 2) beranggotakan siswa sekolah yang bersangkutan; 3) tidak harus memiliki badan hukum; 4) berfungsi sebagai laboratorium kegiatan pembelajaran tentang koperasi di sekolah. Keberadaan koperasi sekolah dapat dimanfaatkan sebagai salah satu media pembelajaran praktik langsung para peserta didik dalam menerapkan keterampilan dan keahliannya dalam bidang wirausaha. Dari pernyataan tersebut menunjukkan betapa pentingnya peran koperasi sekolah bagi peserta didik.

Sebagai media yang dapat dijadikan alat untuk mengembangkan kewirausahaan di lingkungan sekolah, pemberdayaan koperasi sekolah juga mempunyai fungsi ganda yaitu sebagai organisasi pendidikan dan sekaligus sebagai organisasi usaha. Koperasi sekolah dapat dijadikan sarana bagi peserta didik untuk belajar melakukan usaha kecil-kecilan, mengembangkan kemampuan wirausaha, belajar berorganisasi, belajar menyelesaikan masalah dan mendorong kebiasaan berinovasi ( Sijabat, 2014 ). Koperasi sekolah dapat diberdayakan sebagai sebuah sarana dan wadah yang strategis di lingkungan sekolah untuk menumbuhkan karakteristik jiwa entrepreneur pada peserta didik. Hal ini karena koperasi sekolah mempunyai fungsi legal bagi sekolah dan peserta didik untuk melaksanakan aktivitas usaha atau unit usaha yang berorientasi pada pemenuhan kebutuhan peserta didik dan sekaligus berfungsi sebagai wahana pembelajaran.

Menurut Kurniawan (2014), adanya koperasi sekolah dapat mendorong siswa untuk menumbuhkan motivasi dalam berwirausaha, mendorong peserta didik untuk dapat mengembangkan keterampilan wirausaha melalui kegiatan pembukuan, pencatatan persediaan, penggunaan komputer, pelayanan jual beli dan kegiatan-kegiatan lainnya yang terkait dengan kewirausahaan. Selain itu peserta didik juga dilatih untuk dapat bertanggung jawab, memiliki kemandirian, memiliki semangat yang tinggi dan dapat menjalin kerjasama dengan kelompoknya.

Peran Koperasi sekolah sebagai salah satu unit usaha sekolah yang dijalankan oleh peserta didik, akan mampu melatih mereka untuk dapat memiliki rasa percaya diri, mengambil resiko, mampu berinovasi dan mampu memanfaatkan peluang yang ada. Karakteristik tersebut adalah cerminan jiwa seorang entrepreneur, yang akan diperoleh dari kegiatan koperasi sekolah. Selain itu, karena koperasi sekolah adalah sebuah organisasi, maka peserta didik juga akan 
terlatih untuk menjadi seorang pemimpin dan menjalankan perannya masing-masing pada organisasi tersebut. Pengalaman-pengalaman yang diperoleh dari kegiatan koperasi sekolah , diharapkan dapat dijadikan bekal untuk memasuki kehidupan bermasyarakat setelah peserta didik lulus dari sekolah.

Setiap sekolah memiliki budaya yang merupakan kepercayaan, nilai-nilai, pola-pola yang mendalam, tradisi dan kebiasaan serta cara pandang dalam menyelesaiakan masalah yang terdapat pada sekolah tersebut. Budaya yang ada di sekolah dapat digunakan untuk menanamkan nilai-nilai dan jiwa entrepreneurship kepada peserta didik. Menurut penelitian Anggreani (2020), nilai-nilai entrepreneurship yang dapat diintegrasikan melalui budaya sekolah antara lain adalah 1) mandiri; 2) berani mengambil resiko; 3) kreatif; 4) kejujuran; 5) kepemimpinan; 6) berorientasi pada tindakan dan 7) kerja keras. Nilai-nilai tersebut ditanamkan dengan cara menerapkan dan mengkondisikan budaya sekolah melalui pembiasaan yang diharapkan akan berdampak pada pribadi peserta didik dan kegiatan belajar mengajar seharihari.

Pembiasaan nilai mandiri dapat dilakukan dengan cara memberikan tanggung jawab kepada peserta didik untuk menjaga kebersihan lingkungan kelas dan penekanan agar tidak tertumpu pada orang lain dalam melakukan aktivitasnya. Sedangkan untuk menanamkan nilai kreatif melalui budaya sekolah, dapat dilakukan dengan cara menyediakan mading ( majalah dinding ) agar peserta didik dapat dengan bebas menuangkan ide kreatifnya. Berbagai macam perlombaan yang digelar pada event-event tertentu juga dapat dijadikan sarana untuk menggali kreativitas peserta didik.

Nilai orientasi pada tindakan dapat ditanamkan melalui kegiatan gotong royong, tidak membuang sampah sembarangan dan mengembangkan sikap saling peduli antar sesama. Bekerja berdasarkan budaya prestasi, dan sekolah memberikan penghargaan kepada peserta didik yang berprestasi akan mendorong motivasi peserta didik untuk selalu mengejar prestasinya. Hal ini akan berimbas memicu peserta didik untuk bekerja keras dalam meraih prestasinya, dan terbiasa untuk menyiapkan segala sesuatu dengan cermat untuk mencapai masa depannya. Hal sederhana yang dapat dilakukan untuk menanamkan nilai berani mengambil resiko adalah dengan mengintegrasikan pada proses pembelajaran yaitu dengan cara memberikan quiz yang menerapkan aturan penambahan point jika menjawab dengan benar dan pengurangan point jika menjawab salah. Apabila ini dijadikan budaya sekolah, maka peserta didik akan terbiasa dan terlatih untuk berhati-hati dalam pengambilan keputusan, untuk meminimalisir pengurangan point.

Sedangkan untuk penanaman nilai kepemimpinan salah satu cara yang dapat digunakan adalah saat penunjukan petugas upacara bendera. Tim yang ditunjuk harus mampu mengkoordinasi petugas pada timnya, sehingga dibutuhkan seorang peserta didik yang memiliki jiwa kepemimpinan. Nilai entrepreneur lainnya yang tak kalah penting adalah kejujuran. Pengimplementasian nilai kejujuran ini dapat dilakukan dengan penerapan kantin kejujuran, gerakan tidak mencontek saat ulangan. Tindakan patuh dan disiplin terhadap tata tertib juga dapat dijadikan sarana untuk melatih kejujuran siswa. Penanaman nilai-nilai entrepreneurship melalui budaya sekolah harus dilaksanakan secara terus menerus, dijadikan kegiataan rutin dan konsisten. Tak kalah penting, jika dalam sebuah sekolah menghendaki agar peserta didik berperilaku sesuai dengan nilai-nilai budaya dan karakter bangsa, yang dalam hal ini termasuk budaya nilai entrepreneurship, maka mulai dari jajaran kepala sekolah, guru dan tenaga kependidikan adalah orang yang paling utama dalam memberikan keteladanan (Sulistyowati : 2012).

Penanaman nilai-nilai entrepreneurship kepada peserta didik ini sangat penting untuk membekali mereka dengan kecakapan hidup ( life skill). Di era globalisasi ini kita harus dapat mengubah mind set dari "setelah lulus sekolah mencari kerja menjadi setelah lulus sekolah dapat menciptakan lapangan pekerjaan". Hal ini mengingat persaingan yang sangat tinggi di segala bidang terjadi di era globalisasi ini. Menumpuknya jumlah tenaga kerja dari tahun ke 
tahun menyebabkan para lulusan sekolah tidak seluruhnya dapat terserap oleh lapangan pekerjaan, sehingga akan menambah angka pengangguran di Negara kita.

Pengembangan dan pembekalan life skill kepada peserta didik sangat diperlukan, seperti pernyataan Darwyansyah (2006), bahwa ada beberapa alasan pentingnya membekali peserta didik dengan life skill agar mereka kelak sukses dalam kehidupannya. Keterampilan atau kecakapan hidup tersebut antara lain adalah 1) disiplin, jujur, amanah, cerdas, sehat, bugar, pekerja keras, pandai mencari dan memanfaatkan peluang, mampu bekerjasama dengan orang lain dan berani mengambil keputusan; 2) dengan bekal keterampilan hidup yang diberikan oleh sekolah kepada peserta didik diharapkan adanya kesesuaian dengan kecakapan atau keterampilan yang dibutuhkan oleh peserta didik setelah lulus, untuk diterapkan dalam kehidupan sehari-hari.

\section{PENUTUP}

Dari hasil penelitian ini dapat disimpulkan bahwa penanaman nilai-nilai entrepreneurship kepada peserta didik sangat dibutuhkan, mengingat mereka hidup di zaman global dengan tingkat persaingan antar individu yang sangat tinggi dalam berbagai bidang. Tujuan penanaman nilai-nilai entrepreneurship ini agar mereka mempunyai bekal kecakapan hidup ( life skill ) setelah lulus sekolah, sehingga mereka dapat survive, mandiri dan dapat menjalani kehidupan yang lebih baik ke depannya. Ada beberapa cara yang dapat dilakukan oleh sekolah dalam menanamkan nilai-nilai entrepreneurship kepada para peserta didiknya yaitu 1) melalui proses pembelajaran menggunakan model pembelajaran Project Based Learning ( $P B L$ ) Market Day yang sering juga disebut dengan program Market Day. Program ini bertujuan untuk mengembangkan keterampilan berwirausaha; 2) Pemberdayaan Koperasi Sekolah, dimana peserta didik dapat menjadikannya sebagai media untuk berpraktik langsung dalam menerapkan keahliannya di bidang wirausaha; dan yang ke 3) adalah melalui budaya sekolah. Pembiasaan-pembiasaan dan keteladanan dari seluruh warga sekolah yang dilaksanakan secara terus menerus dan konsisten akan dapat membentuk nilai karakter dan perilaku entrepreneurship.

\section{DAFTAR PUSTAKA}

Anwar (2006 ). Pendidikan Kecakapan Hidup Konsep dan Aplikasi. Bandung : Alfabeta.

Anggreani, E. \& Desy Husmita (2020). Upaya Menanamkan Nilai Nilai Entrepreneurship Kepada Siswa Melalui Budaya Sekolah. Makalah pada Prosiding Seminar Nasional Pendidikan Program Pasca Sarjana Universitas PGRI Palembang . Diakses dari https ://jurnal:univpgri-palembang.ac.id/index.php/Prosiding/article/view/3820/3583.

Badan Pusat Statistik (2020). Tingkat Pengangguran Terbuka (TPT ). (online) www.bps.go.id.

Diakses pada tanggal 21 april 2021.

Darwyansyah, dkk (2006). Perencanaan sistem Pengajaran Pendidikan Agama Islam. Jakarta : Faza Media.

Departemen Pendidikan Naioanal (2008). Kamus Besar Bahasa Indonesia. Jakarta : Gramedia. Dongoran, Nisa Sihombing \& Purba (2016). Analisis Jumlah Pengangguran dan Ketenaga

Kerjaan Terhadap Keberadaan Usaha Mikro Kecil dan Menengah di Kota Medan. Jurnal Edu Tech 2 (2), 59-72

Fatimah, S. (2014). Menumbuhkan Jiwa Wirausaha Muda dalam Pembelajaran Ekonomi Criksestra. Jurnal Pendidikan dan Kajian Sejarah 3(4).

Kemendiknas (2006). Modul I : Membangun Jiwa Kewirausahaan. Bahan Pelatihan untuk Calon Wirausaha. Jakarta : Kemendiknas.

Kurniawan, Chandra (2014). Peranan Koperasi Sekolah Sebagai Pengembang Keterampilan Kewirausahaan. Jurnal Media Wahana Ekonomika 11(2).

Muhaimin (2003). Arah Baru Pendidikan Islam. Bandung : Nuansa

Nasution, Arman H. et.al (2007). Entrepreneurship Membangun Spirit Technopreneurship. Yogyakarta : Andi 
Nurbudiyani, I. (2013). Model Pembelajaran Kewirausahaan dengan Media Koperasi Sekolah di SMK Kelompok Bisnis dan Managemen. Jurnal Pendidikan Vokasi 3(1)

Rohmah, F. (2020). Menumbuhkan Kewirausahaan Melalui Market Day. https://radarsemarang.jawapos.com/rubrik/untukmu-guruku/2020/03/25/menumbuhkankewirausahaan-melalui-market-day/. Diakses pada tgl 27 April 2021 pukul 8.37

Sakdiyah, H. (2010). Revitalisasi Entrepreneurship di Pondok Pesantren. Jurnal Al Ihkam V(2).

Saroni, Muhammad (2012). Mendidik dan Melatih Entrepreneur Muda : Membuka Kesadaran Atas Pentingnya Kewirausahaan Bagi Anak Didik. Yogyakarta : Ar Ruzz Media.

Sarosa, Pietra (2005). Kiat Praktis Membuka Usaha, Becoming Young Entrepreneur, Dream Big Star Small, Act Now. Panduan Praktis \& Motivasional Bagi Kaum Muda dan Mahasiswa. Jakarta : Alex Media komputindo.

Sijabat, Osco P. ( 2014 ). Peranan Koperasi Sekolah dalam Melatih Kemampuan Entrepreneur Siswa SMK HKBP Pematang Siantar. Lembaga Penelitian dan Pengabdian Masyarakat Universitas HKBP Nommensen : Medan.

Sulistyowati ( 2012 ). Implementasi Kurikulum Pendidikan Karakter. Yogyakarta : Citra Adi Parami.

Suriani, Ni. Made ( 2014 ). Entrepreneurs. Yogyakarta : Graha ilmu.

Suryana ( 2006 ). Kewirausahaan Kiat dan Proses Menuju Sukses. Jakarta : Salemba Empat.

Tim Pengembang Ilmu Pendidikan ( 2007 ). Ilmu dan Aplikasi Pendidikan Bagian IV. Bandung : PT Imperial Bhakti Utama.

Zultiar, I., \& Leonita, S. ( 2017 ). Menumbuhkan Nilai Kewirausahaan Melalui Kegiatan Market Day. Jurnal Ilmiah Ilmu Ekonomi 6(11). 